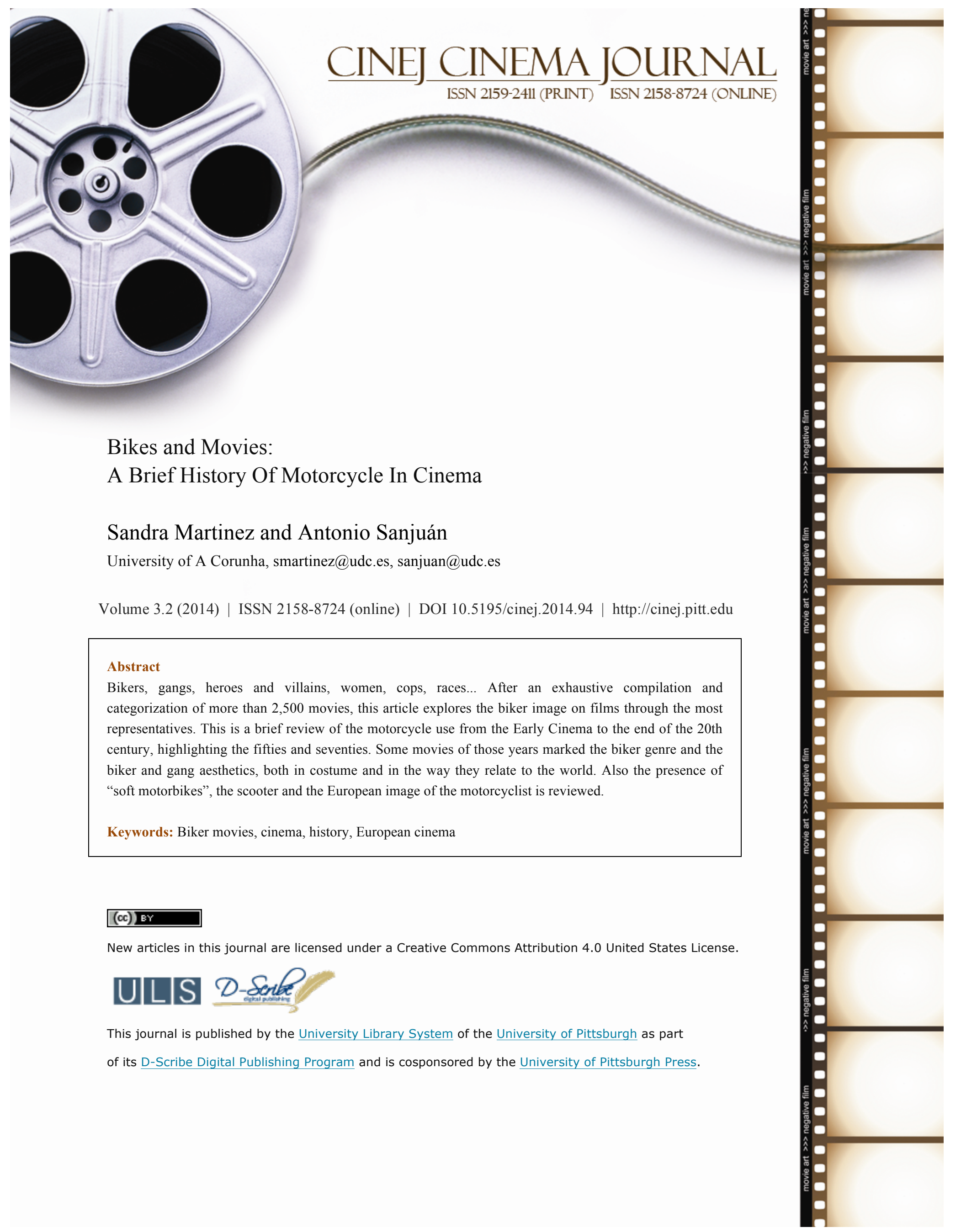




\section{Bikes And Movies: A Brief History Of Motorcycle In Cinema}

\section{Sandra Martinez and Antonio Sanjuán}

\section{Introduction}

In order to provide a more in-depth look at cinema portrayals of motorcycles and the people who ride them, we have begun a compilation of the most popular, and some significant but less well-known movies. More than 2,500 movies were introduced in our database. Two methods were used to determine which movies should be included:

First, we posted an open-ended poll question on popular websites for motorcycle riders and film enthusiasts. The question was "What motorcycle movies do you remember?" A blog was published with their and our contributions. Second, Imdb.com, Imcdb.com, on line film archives and, obviously, Google and YouTube were reviewed with the following criteria:

a. The keywords motorcycle, motorbike, bike, biker, scooter or moped appear in the title or in the plot.

b. The movie has races, chases, gangs or police motorcyclists; or is a biopic or road movie.

c. The motorcycle is ridden by main or secondary characters.

d. The motorcycle is in a major or relevant scene.

e. The motorcycle appears for one minute or more.

After an exhaustive compilation, the results were classified and categorized according to:

a. type of motorcycle (cruiser, scrambler, scooter, moped, etc.) 
b. sort of rider (male, female, age, main or secondary character, good, bad or neutral person)

c. riding equipment (helmet, jackets, boots, gloves, etc.)

Also the following categories were identified:

1. Classic movies

2. Biker and road movies

3. Scooter and soft bike movies

4. Rockers, Mods and musical films

5. Heroes, Superheroes and other solitary riders

6. Biopics, documentaries and cartoons

Dealing with the trouble of an academic definition about what a motorcycle movie is, four levels were found:

1. The first and probably most important is the biker movie or biker flick. Most of these were part of biker-exploitation and the plots are mainly about gangs or clubs.

2. The second is when the motorbike is the common thread used all the time by one or some main characters. It also includes road movies or races on motorbikes.

3. A third level with movies in which the motorbike is commonly used was found. There are also movies in which there are important or representative scenes with a motorbike.

4. Finally are those in which the motorbike appears, but has no important presence. It is used by a secondary character or is a part of the atrezzo.

Obviously, this is a work in progress so we welcome readers' disagreements, additions and comments. Nevertheless, to date we have identified three historical periods:

1. From the historical beginnings until The Wild One (USA, 1953) 
2. The popularization of motorcycle cinema (1953-1980)

3. The normalization of the motorcycle as product placement, prop and even main theme.

In addition to that, several themes emerged from the forum discussion, so some were considered as analysis fields: bike gangs and clubs, military motorcycles, police motorcyclists, women, gender and sex, great chases, romantic or tender motorcycles, long-haul travel, teenagers and bikes, road safety, music and bikes, countries and their different bikes, scooters, sidecars, equipment, biopics, races and competitions, superheroes and heroes, vampires, zombies, werewolves and demons, mid-life crises, special and futuristic designs for cinema, inherited motorcycles, purchase power and high standard of living, rowdy and comic bikers, actor and actress riders and product placement

\section{The Beginnings (1895-1953)}

Ten years after the birth of cinema in 1895, A Motorbike Adventure, directed by Alf Collins, was the first motion picture that included a motorcycle both in the title and in the storyline. This short is a British comedy produced by Gaumont in 1905, nine years before Mabel at the Wheel (USA, 1914), the movie thought to be the first by lots of cinema and motorcycle lovers. A motorbike adventure could seem trivial, but an important detail is remarkable: this first performance of a motorbike ends in an accident.

By the end of the first decade of the twentieth century, film was a global phenomenon. Bikes too, in spite of cinema. In fact, very early on the cinema portrayal of motorbikes was negative. Motorcycles were presented as fast, unstable and dangerous vehicles. Three examples are Drunken motor cyclist $(\mathrm{UK}, 1906)^{1}$-it is easy to imagine what happens-; Motorcyklisten 
(Denmark, 1908) shows a young biker who drives wildly his Ellehammer motorbike and knocks into pedestrians; and The Uncontrollable Motorcycle (UK, 1909), directed by Walter R. Booth, in which the motorbike wrecks a house.

During the same years three films were shot with women riders: Aunty's Motor Bike (UK, 1907), Auntie tries a Motor Bike (UK, 1908) and Margaret's motor rides (USA, 1911). This is particularly relevant viewed from the current perspective. In the beginning, motorcycles were not only for men.

Other titles are of those years are: The Motor Cyclist (UK, 1909), Swank buys a motorbike (France, 1911); Alkali Ike's Motorcycle (USA, 1912), written and directed by Gilbert M. 'Broncho Billy' Anderson, best known as the first star of the Western film genre; and $A$ Motorcycle Adventure (USA, 1912) directed by Marshall Stedman.

How a motor bicycle is made (UK, 1912) deserves special mention. The movie is one of the first promotional films ever to be shot. Dudley Noble performed the role of a motorcycle tester. He was also a competition rider and became one of the British automobile industry's pioneering publicists. The movie ends with a sequence of Dudley accidentally falling off his Rover motorbike.

In 1913 there are other titles such as: A crazy motor ride (Italy, 1913) or The Doctor's orders (USA, 1913), directed and performed by James Neill, with two shining Indian Twins. There is not too much information about that movie. However it is easy to find the synopses of Pimple's motor bike (USA, 1913) ${ }^{2}$. Directed, written and performed by Fred Evans and his brother Joe, this short comedy deals with Pimple, the main character, who sees a bike in a shop window and is fascinated by it. Pimple's motor bike is truly a "motorcycle movie". 
These fifteen movies were the pioneers, but 1914 was coming. The history of motorcycle movies officially begins with Charles Chaplin and his Mabel at the Wheel. Directed by Mabel Normand (Mugno 1998), known as the "Queen of Comedy", and Mack Sennett, one of the three Keystone Studios founders.

This slapstick film has gone down in history for several reasons. This is the first tworeel comedy in which Charles Chaplin appears. There were problems among Chaplin, Normand and Sennett and, due to this circumstance, Chaplin started to write and direct his own movies. Actually, this motion picture is a car race movie, filmed one year before The Race (USA, 1916), which is often considered the first. So we can say that the first car race in movie history was won by a woman... who simply fell off a bike.

Mabel at the Wheel is also the first commercially successful film with an important bike sequence. The film is a typical Keystone comedy ${ }^{3}$, with a villain (Chaplin) going over a bump, and a girl (Normand) flying off into a mud puddle. The motorcycle of choice (a light Thor IV, single-cylinder, with bad suspension and worse brakes) is peculiar. Harley-Davidson, Excelsior and Indian were already famous brands and, especially the third, were landmarks in the world of racing. But Thor is the one that holds the place of honor in the history of film. The company had a short life as a motorcycle manufacturer, so in this case the "blockbuster" did not become a success for the "product placement" itself. But from that moment, the appearances of bikes in movies would go for leading brands -with excellent results-.

Indeed, in 1914, the age of big bikes started. And women were important again. Helen Holmes started in a dramatic episode of The Hazards of Helen ${ }^{4}$ (USA, 1914) with an Indian. Holmes was a brave heroine, however she needed a stunt-double: Helen Gibson ${ }^{5}$ was the woman who rode the bike. The Hazards of Helen was in direct competition with The Perils of 
Pauline, another adventure series with a female protagonist (and the occasional motorcycle) at the time of the women's struggle for the right to vote. The bike appeared in the $26^{\text {th }}$ chapter, titled The Wild Engine (USA, 1915). 'Engine' did not refer to a bike, but a locomotive. Helen came to the rescue on her Indian which, jumping a bridge, ends up falling into the sea. The heroine works for a railway company, so she sends them the bill for the bike: 260 dollars.

More than 50.000 movies were filmed in the first two decades of the twentieth century, but only a few of them included bikes. A Motorcycle Elopement (UK, 1914, and USA, 1914 and 1915), Love, Speed and Thrills (USA, 1915), in which the first sidecar of movie history appears, Love, Loot, Crash (USA, 1915), and Her Torpedoed Love (USA, 1917) continued the line of Mabel at the Wheel adding the famous "Keystone Cops". Smashing Through (USA, 1918), The Roaring Road (USA, 1919) and Excuse my Dust (USA, 1920), the last two starring the "Steve McQueen" of the age, Wallace Reid. These films featured big bikes, frequently with sidecars, which were not too efficient: or bikes which had accidents or were clearly inferior to cars.

Perhaps one might best round out the picture of the 1920 s by focusing attention on the stars. Harold Lloyd — Get Out and Get Under (USA, 1920), Doctor Jack (USA, 1922), Girl Shy (USA, 1924), Hot Water (USA, 1924) or Speedy (USA, 1928)—, Buster Keaton —One week (USA, 1920), The Scarecrow (USA, 1920), Convict 13 (USA, 1920) Hard Luck (USA, 1921), Sherlock Jr. (USA, 1924)—, Stan Laurel \& Oliver Hardy — On the front page (USA, 1926), Fluttering Hearts (USA, 1927), Two Tars (USA, 1928)—, "Snub” Pollard — The Yokel (USA, 1926) — were all successful comedies with motorbike sequences. Even Helen Holmes used a bike again in The Fast Freight and Pirates of the Sky (both filmed in 1926). Movies such as these shaped a clear stereotype: "From these beginnings, the motorcycle has become a 
staple of chase scenes in film, from romantic comedies to action dramas. While in the early screwball comedies the motorcycle took the hero toward his desired object, in later films the trajectory was reversed as the bike became a means of escape" (Alford and Ferriss 2007).

Bikes are always more difficult to drive than cars and can be used to perform impressive acrobatics. In those years, some of these bikes had flimsy chassis, weak brakes, short suspension travel and even no clutch or gears. Because of this, stunts had great merit and the audience applauded the spectacle of this modern gadget, with funny actions, ridiculous chases, falls, jumps ... and almost circus-like skills.

For example, in One Week, Keaton rides over the handlebars of an Indian Powerplus. In The Scarecrow, he drives a Harley-Davidson Model $\mathrm{J}$ into a priest who is then wedged over the sidecar to marry him to his girlfriend on the bike. In Sherlock $J r$. (USA, 1924), Keaton makes a hilarious ride, again on the handlebars of a riderless motorcycle.

However, there are other more conventional uses. Get Out and Get Under (USA, 1920) includes a typical cop chase. In Hot Water (USA, 1924) the police motorcyclists do not wear uniforms but leather jackets, and Harold Lloyd mistakes them for a couple that is riding their motorcycle with a sidecar. In the first sequence of Convict 13 (USA, 1920), Keaton goes to play golf on a Harley-Davidson Model F, with sidecar. Hard Luck (USA, 1921) shows Buster trying various ways to commit suicide. This is a motorcycle specific gag that plays with the element of surprise.

Some of these recurring gags turn into classics. Fast and Furious (the 1924 film, not the other 15 movies with the same title contained at imdb.com) is the first movie in which the protagonist gets in the sidecar but when the bike starts moving, the sidecar stays put. Groucho 
and Harpo Marx improved the joke in Duck Soup (USA, 1933), and the intro of British TV series George and Mildred (UK, 1976-1979) would use the gag once more.

Great filmmakers incorporate motorcycles in their movies: Cecil B. DeMille in Manslaughter (USA, 1922), as police motorbike; King Vidor in The Big Parade (USA, 1925), as military motorbike; and, as symbol of modernity, Lev Kuleshov with Neobychainye priklyucheniya mistera Vesta v strane bolshevikov (aka The Extraordinary Adventures of Mr. West in the Land of the Bolsheviks, Soviet Union 1924), Fritz Lang with Spione (Germany, 1928) or even Dizga Vertov in his documentary Chelovek s kino-apparatom (aka The man with a movie camera, Soviet Union, 1929).

Three more documentaries ${ }^{6}$ can be mentioned: Der Kilometerfresser ${ }^{7}$ (Austria, 1925), by Karl Imelsky; Mit dem Motorrad über die Wolken (Austria, 1926), by Rübelt Lothar; and Première traversée du Sahara à moto (France, 1927). Perhaps, those are the "grandparents" of Long way round (McGregor and Boorman, UK, 2004).

In the last years of silent motorcycle movies, there are two unforgettable actors, one famous and one who should be: Charley Chase and Edgar Dearing. Charley Chase ${ }^{8}$ was "an incredibly prolific star comedian of the twenties and thirties who produced hundreds of short comedies in both the silent and the sound eras" and for his contribution to the motion picture industry, he has a star on the Hollywood Walk of Fame.

Edgar Dearing ${ }^{9}$ was the American actor who most performed the role of a motorcycle cop in Hollywood films, in 47 movies at least. In the 20s: Should Men Walk Home? (USA, 1927), Limousine Love (USA, 1928), with Charley Chase; Fair and Muddy (USA, 1928); and The Jazz Age (USA, 1929), in addition to the aforementioned Hot Water, On the Front Page 
and Two Tars. Dearing continued working until 1964, and his last role was the one of a motorcycle cop in She Wrote the Book (USA, 1946).

By the end of twenties, silent movies and talkies competed on the big screen. At this point in history, the portrait of the motorcycle in film was formed by a little more than half a hundred silent movies (69 movies, shorts, documentaries and cartoons to be precise - until 1930 were found and entered in our database). During this time, one in three movies show a police motorcycle involved in chases, and nine out of ten riders are males.

From 1930 until 1953, at least 172 motorcycle movies were filmed. Cops are still those who most frequently used bikes in movies. For example, two Oscar winners: The Awful Truth (USA, 1937), with Edgar Dearing as a cop; and The pride of the Yankees (USA, 1942), in which police officers escort the wedding car of Gary Cooper (as the famed baseball player Lou Gehrig,) and his girlfriend.

Aside from the police motorcycle, in this period there were two celebrated race movies: No Limit (UK 1935), a comedy starring George Formby and Once a Jolly Swagman (UK, 1948), a romantic drama starring Dirk Bogarde, both transmitting a positive image of bikes and riders. Cocktails had already included motorcycle competition scenes in 1928, however it was not a race movie. Another movie, much less known, is Motorkavaljerer ${ }^{10}$ (Sweden, 1950), a romantic comedy in which bikes are the main character, obviously associated with speed but also with engineering: a gang of young motorcycle enthusiasts construct an entirely Swedishbuilt machine, which they gave the name of "Fantomen".

Prends la Route (France, 1936) is, perhaps, the only motorcycle movie of these years which serves as a symbol of freedom and youth. Schwarzwaldmädel (West Germany, 1950) was considered the first heimatfilm ${ }^{11}$ ever produced and includes many scenes with a "happy" 
scooter, a Riedel Till 100. Professor Nachtfalter (West Germany, 1951) with a lot of happy scooters (maybe the first movie featuring Vespa) is another example of that.

During these years, motorcycles were considered dangerous but not fatal. The Danish short De nåede faergen (1948) was an exception. This short movie is meant to be propaganda against fast driving - telling the story of a young couple riding at high speed to catch a ferry.

Two movies with the "wall of death" should be noted: Spare a Copper (UK, 1941), a comedy starring George Formby; and the drama There is another Sun (UK, 1951) in which stars Maxwell Reed as an ex-speedway star who rides the 'Wall of Death' in a fairground.

That said, we are still talking about exceptional cases. Motorcycles are rare in films in this period. Even in war or military movies only a few motorcycles appear on camera. An example is I Was a Male War Bride (USA, 1949), directed by Howard Hawks, starring Cary Grant and Ann Sheridan. The motorcycle is driven by the woman and the man has to ride in the sidecar. Another cross-dressing comedy with another woman riding is Czy Lucyna to dziewczyna? (Poland, 1934), known as Is Lucyna a Girl? A feisty young woman (Lucyna) comes back to Poland from Paris with an engineering degree and a sense of feminist liberation. She works and dresses as a man and rides a motorcycle. It seems that women are more masculine if they drive motorbikes and feminize men if they ride in sidecar.

Returning to the military motorcycle, we are struck by the absence of scenes with motorcycles, especially considering the importance of motorcycles in the U.S. and Nazi army during WWII that later would become very popular. Perhaps the only noteworthy British film of this time is The Life and Death of Colonel Blimp (1943) with an opening scene full of military Rudge Specials. On the other side of the war, we can see Nazi bikes in The North Star 
(USA, 1943). The presence in film of the Nazi motorcycles would be more usual two decades later.

We are not able to close this historical period without mentioning the first superhero riders: The Vigilante (USA, 1947) and Captain America (USA, 1944). The bikes are unimportant but become a precursor for subsequent heroes and superheroes.

To summarize, until the beginning of the biker genre the rare presence of motorcycles and scooters in movies is associated with men (mostly policemen) or with the positive values of sport, with some danger, but not excessive, and with youth and happiness. All this changed in the fifties.

\section{The Biker culture is born}

The leather clothing, the clubs and motorcycle gangs became hallmarks of motorcycle films between 1950 and 1970. In those years the image of the biker as a renegade outlaw who rides free, sometimes travelling alone on the roads, was constructed. Also, the image of gangs and clubs was born. The biker became part of a new group that shared the passion for the road, the freedom and, sometimes, the violence.

At the beginning of the fifties, bikers wore leather jackets and caps instead of helmets. Movies such as Farlig Kurva (Sweden, 1952) or The Pace That Thrills (USA, 1952) showed this kind of riders, and their portrayal was not terrifying (Lagergren 2007). The reason for this is in the origins of the motorcyclist clubs. The oldest known biker association is the Yonkers MC from New York, dating from $1903^{12}$. It all started as a group of motorists who spontaneously began gathering to "do a few miles".

In the same year the American Motorcyclist Association (AMA) was born, and the 
International Motorcycle Federation (FMI) did so in 1904. The boneshakers, as they were called because of their riding over cobbled roads, took part in the first races, skill competitions and round trips. Those activities were part of the American Gipsy Days.

After the First and Second World Wars, veterans returned to the United States covered with honors. Some of them were trained to ride bikes or repair them. However, in most cases they left their jobs or family, so they began to come together in biker clubs. Many came back with injuries or psychological disorders, so they felt like renegades and disenfranchised, sheltering themselves in the clubs. Some of those veterans used noisy motorcycles, did illegal races and covered their bikes with Nazi icons, used in WWII for counting German casualties.

But most of the motorcycle clubs were born to promote the motorcycling sport. In 1936 the MC Cook from Chicago was created. Their members took part in the wall of death and mountain races all over the United States.

The film The Pace That Thrills (USA, 1952) reflects in part what happened in the motorcycle clubs in those years. Directed by Leon Barsha and produced by Howard Hughes, the movie is about a rider who falls in love with a journalist. As a starting point, the plot is used to show races, skills and small crashes filmed from reality.

However, the incidents on July 1947 in Hollister meant a change in the image perception of the motorcyclist and the unfortunate coining of the term $1 \%$ outlaws.

The László Benedek movie The Wild One (USA, 1953) is a dramatized version of that event and is considered, at the same time, as the first real biker film. For the production, Marlon Brando used his own bike, a 1950's Triumph Thunderbird 6T. The movie is wellknown because of the iconography and aesthetics of Brando: the jeans, the caps, the leather jackets and the sunglasses from the movie became very popular. 
Nevertheless, the biker image the movie constructed was negative. After the release, Triumph complained to Stanley Kramer for the use made of their motorcycles. Later in the sixties, however, Gil Stratton Jr. ${ }^{13}$ became a star of advertisements. Nowadays, the iconic image of the film is used to promote Triumph clothes.

Speaking of the fifties, One Way Ticket to Hell (USA, 1955) deserves special mention. The movie followed similar aesthetics as The Wild One, but the intention of the movie was not only entertainment, but also education. Bike competitions, races, and lots of fights are an important part of the plot of these movies. Moreover, the motorcycle presence was important in other car race movies like Hot Car Girl (USA, 1958) or The Wild Ride (USA, 1960), with a rather young Jack Nicholson.

The influence of these films was remarkable, but it was not until the sixties when the biker genre really started. Roger Corman, the king of "B movies", directed The Wild Angels in 1964, considered the first $100 \%$ outlaw biker film ${ }^{14}$.

Because of the Hunter S. Thompson book, Hell's Angels: A Strange and Terrible Saga of the Outlaw Motorcycle Gangs, at that moment the Hell's Angels were on everyone's lips...

Despite being sold as if the Hells Angels had participated in the film, they did not like it at all. Corman was sued and forced to pay about $\$ 10,000$ (instead of the original five million initially requested) and the commitment that no filmmaker could use the club logo without authorization.

Following the Corman success another great Series B and King of Nude director, Russ Meyer, tried to imitate the biker genre with Motor Psycho (USA, 1965). In 1967 Roger Corman tried again with the biker movie genre: Devil's Angels. Scripted by Charles B. Griffith and starring John Cassavetes, this film is no less violent but is interwoven with humorous touches. 
The idea of the film is that bikers are people unintentionally involved in illicit situations.

One year earlier, the avant-garde filmmaker Kenneth Anger released Scorpio Rising (USA, 1964) as an experimental film about motorcycle clubs. The movie became popular because of its soundtrack of thirteen pop artists: Elvis Presley, Ricky Nelson, The Angels, The Crystals, Bobby Vinton or Ray Charles among others. It is also highlighted for the use of the psychedelic images, satanic rituals and necrophilia.

Three years later, Andy Warhol made a film in which a member of a biker gang has a conversation with him after having a shower. In this film, Bike Boy (USA, 1967), there is no motorbike but the role represented by the biker is a figure of rebellion in American popular culture in the post-Second World War era. The motorcycle also features prominently in another Andy Warhol film: the unfinished Batman Dracula and Couch $^{15}$. Following this particular style Vicious Cycles (USA) highlights in 1967. The movie is a biker film without bikes, filmed with stop-motion animation techniques. Directed by Chuck Menville and Len Janson, it is a parody of the genre in which there is a wild motorcycle road gang, whose bikes leave tire tracks on the highways, fuming and boasting about a girl with the members of a scooter-riding club.

Uniquely, Hells Angels on Wheels (USA, 1967) does not follow the trends and patterns of the biker genre established by previous films, however Jack Nicholson became popular as a biker in this movie. The endorsement of a real Hells Angels guaranteed the success of the film as well as the biker genre in the United States. The film celebrates fun, fights, gangs and the goodness of friendship, the bikes and the road. The most common bikes in this movie are Harley-Davidsons and BSAs. The success of the real Hells Angels promotion was guaranteed, as well as the success of the biker genre in the United States. 
Movies with the words angel, devil or hell were frequent on those years. Most of them were an important part of the biker exploitation films and because of that relied on the necessary elements to be identified as part of the genre: drugs, fights, citizen harassment, guns and definitely motorbikes.

The Glory Stompers (USA, 1968) is about two types of biker gangs: one which believes in fun and friendship as a way of life; and the other which is violent and furious, always looking for trouble. Despite being a low cost film, it is full of action - although without the brutality of other biker movies. A year later, Sisters in Leather (USA, 1969) dealt with homosexuality in a movie in which a group of lesbian biker women blackmail a married man over his affair with another woman.

Two films of the late sixties stand out. Both were popular among bikers, although they did not like them in the same way. While Easy Rider (USA, 1969) was successful among the audience, the $1 \%$ outlaw biker did not enjoy it. However, it is not only one of the best of the genre, but also one of the greatest road movies of the century. Hells Angels 69 (USA, 1969) was recognized as one of the films that better caught the spirit of the true outlaw clubs. The Oakland Hells Angels, with Sonny Barger and Terry the Tramp, took part in the movie and even had some dialogue.

\section{The seventies. A second batch for the biker genre}

Easy Rider meant the association of driving custom bikes with freedom. With this movie, bikers and drugs definitely became partners, but at the same time it helped to conceive the bikers as non-violent people. However, in those years, many biker clubs (including the Hells Angels) declared themselves in favor of war and offered to fight in Vietnam.

CINEJ Cinema Journal: Bikes And Movies: A Brief History Of Motorcycle in Cinema

Volume 3.2 (2014) ｜ ISSN 2158-8724 (online) | DOI 10.5195/cinej.2014.94 | http://cinej.pitt.edu 
Jack Nicholson starred in Rebel Rousers (USA, 1970). The movie expresses the rebellious youth of the United States in the sixties, both in groups and individually. There are other great movies of the genre in the same year, some of higher quality: Little Fauss and Big Halsy (USA, 1970) and the above mentioned C.C. and Company.

Some of the movies of the time started to incorporate soldiers returned from the Vietnam War as characters. Something similar happens with The Black Six (USA, 1973), a movie about black soldiers in Vietnam. In the seventies some filmmakers turned to horror hybrids with movies like Satan's Sadists (USA, 1969), Werewolves on Wheels (USA, 1971), Psychomania, also known as The Death Wheelers (USA, 1973) and Blood Freak (USA, 1972) to name a few.

The blending of elements from several genres lead to the production of movies such as The Pink Angels (USA, 1971) in which a gay biker gang attack their enemies with makeup. Trying to be humorous and irreverent, the movie accomplishes neither. $J$. C. (USA, 1972) or Road of Death (USA, 1973) were other curious movies of the decade.

In the middle of the seventies the genre became popular with The Northville Cemetery Massacre (USA, 1976), a cult film among bikers. Although bikers had been frequent in exploitation movies, there had not yet been true biker exploitation films. Trip with the teacher (USA, 1975) is a mix of genres, with plenty of sex and violence. The same idea was in the plot of The Dirt Gang (USA, 1972). Parallel to that, there were some interesting documentaries about the motorcycle world: On any Sunday (USA, 1971), with Steve McQueen is maybe the most important; and Dirt (USA, 1978), with rallies and "dirt" as storyline. Continental Circus, from 1972 is a tribute to classic motorcycling, with riders such as Giacomo Agostini, Jack 
Findlay and Santiago Herrero among others. Another important documentary was Hell's Angels takes a mini-break (USA, 1973).

In the late seventies the genres mixed, and in a few years, this meant the rise and overexploitation of biker movies. At the end of the decade the modern image of the bike in cinema was being built. Many films of the previous years led to other curious ones, such as Chopper Chicks in Zombietown (USA, 1989), Knightriders (USA, 1981) or I bought a Vampire Motorcycle (USA, 1990), but they were mostly the death throes of biker exploitation and of the mix of previous genres. Little by little, the genre recovered, and some movies tried to imitate the classical movies of the late sixties and the early seventies.

\section{Meanwhile, in Europe...}

The fifties is also an important decade for European Cinema. 1953 was the release year for another important movie: Roman Holiday. Maybe this is the first movie conceived as a touristic film. Obviously this is not a European movie, but the presence of the Vespa riding on the Roman streets makes the mind of the spectator think about European cinema. Also, the presence of an undercover sweet Princess constructs the image of the "soft" motorbike.

Federico Fellini also used motorbikes in movies such as Le notti di Cabiria (Italy, 1957) and I clowns (Italy, 1971). Meanwhile, Roma (Italy, 1972), a portrait of that city in the thirties, hosts a Laverda $750 \mathrm{~S}$. Other great Italian directors such as Bolognini or Pasolini did the same a few years later. Visconti introduces the Vespa in Bellissima (Italy, 1951) and Dino Risi in Poveri, ma Belle (Italy, 1956) or Belle ma Povere (Italy, 1957). The Vespa became a hallmark of Italy, because of being cheap transport before the Second World War. So, in the movies, this vehicle represented the icon of the popular families. I tartassati (Italy, 1959) is, for 
instance, a comedy about a middle-class family. Fellini shows a Rome from the fifties in $L a$ Dolce Vita (Italy, 1959) and, as could not be otherwise, the Vespa 125 is the paparazzi vehicle. The Vespa also appears in Guardia, guardia scelta, brigadier e marescialo (Italy, 1957), with Aldo Fabrizi and Alberto Sordi. Other movies from Italy showed the motorbike as a common method of rapid transportation, too.

Some movies from Spain, the United Kingdom, France or Italy showed the biker associated with youth, the summer and innocence lost. Blue Jeans (France, 1958) is maybe one of the most popular and really well-known by Vespa lovers. In France, the presence of motorbikes is commonly used in fun or comedic scenes. Music was ever-present in scootermovies. Not only the heimatfilm from German, Switzerland and Austria, but also the British ones. Quadrophenia (UK, 1979), with Sting in the role of Ace Face is the most representative musical movie from Europe. But the cinema talked about the rockers and mods universe some years before: the juvenile worlds were frequently confronted in European movies. Mods versus rockers became popular in the seventies as a symbol of this.

Spanish cinema also used the motorbike in some well-known movies: Bienvenido Mister Marshall (1953), El Pisito (1959), El Cochecito (1960), El verdugo (1963), El Puente (1977) or Larga noche de julio (1974), among others.

The portrayal of the motorbike in the Second World War was formed in those years both in European and American films. The most representative of the sixties is The Great escape (USA, 1963). This includes the most popular scene of history with a military motorbike: Steve McQueen's jump while running away from the Nazis. 


\section{The End of Millennium (1980-1999)}

It would hardly be an exaggeration to say that in the last 20 years of the $20^{\text {th }}$ century there was an explosion of the presence of motorcycles in cinema. Between 1895 and 1980, 792 movies with a rider role are registered in our database. From 1980 to 2000, there are over a thousand. But, paradoxical as it may seem, only a handful of motion pictures from this time can be considered motorcycle movies ${ }^{16}$.

In this period, specific scenes built the portrait of the motorcycle, not movie or genres. It had happened with the sequence of Steve McQueen riding on a Triumph in The Great Escape (1963), which became a veritable bike icon. In the eighties and the nineties this phenomenon increases. Blockbusters such as An Officer and a Gentleman (USA, 1982), Top Gun (USA, 1986) —and its parody Hot Shots (USA, 1991)—, Indiana Jones and the Last Crusade (USA, 1989), Terminator 2 (USA, 1991), Pulp Fiction (USA, 1994), Tomorrow Never Dies (USA, 1997) or Matrix (USA, 1999) include brief but famous bike scenes. All of these sequences did so much more for the image of the bike than actual biker movies.

Ultimately, then, while in the first half of the $20^{\text {th }}$ century motorbikes are a police vehicle and between 1953 and 1980 are, above all, a matter of gangs, during the last two decades of the century, motorcycles are ridden by heroes in rare scenes or by supporting actors in chases with falls, wheelies, skids and jumps.

But this is only part of the picture. Added to this are motorcycles used as a descriptive element of a main character: he is riding a bike because he is a special person. Like An Officer and a Gentleman, in which the Triumph Bonneville is important to express the personality of Zack Mayo (Richard Gere), several movies use motorbikes in the same sense. The Principal 
(USA, 1987), a drama film, starring James Belushi, the Kawasaki Vulcan is shot in quite a few sequences in order to show the tough personality of a high-school teacher with a drinking problem.

Similarly, Raising Arizona (USA, 1987) or the Spanish comedies Mujeres al borde de un ataque de nervios (Spain, 1988) and Amanece que no es poco (Spain, 1988) are three auteur films with very precise uses of bikes. Tron (USA, 1982) and Akira (USA, 1988) are two cult films with motorbikes in an important role. Their bikes became two of the most imitated futuristic designs. Also with animation techniques, in this case stop motion, was Mouse on a Motorcycle (USA, 1995).

Other minority and low cost but salient movies are Knightriders (USA, 1981), Eat the Peach (USA, 1986), The Punisher (USA, 1989 and 2004), Beyond the Law (USA, 1992), Roadside Prophets (USA, 1992), Barb Wire (USA, 1996), and Murdercycle (USA, 1999).

Knightriders, starring Ed Harris and directed by George A. Romero, is a particular road movie with riders wearing medieval helmets and armor. Eat the Peach tells the story of two young people that decide to build their own "Wall of Death" after watching the Elvis Presley movie Roustabout. The Punisher is another typical film of lonely heroes, like Beyond the Law, performed by Charlie Sheen as a cop infiltrated in a biker gang, and the futuristic Murdercycle or Barb Wire.

It is interesting to consider the role of the female biker, like a hyper-sexualised Pamela Anderson performing Barb Wire, girl gangs of Chopper Chicks in Zombietown (starring Billy Bob Thornton) or Virgins from Hell (Indonesia, 1987). They are always characters developed from a male perspective, frequently victims or treated like objects, not people. One exception is 
the documentary Motorcycles Diaries (USA, 1987) produced by women motorcyclists about female riders on sport, drag, road or motocross bikes.

Finally, the case of Harley Davidson and the Marlboro Man (USA, 1991) ${ }^{17}$ serves to illustrate that the male biker stereotype played by well-known actors such as Mickey Rourke or Don Johnson may face critical and financial failure despite brand names in titles. This raises the whole question of product placement. Philip Morris ${ }^{18}$ sued to have its name deleted from the title. But this marketing strategy would be used frequently in the motorcycle movies of 21 th century.

\section{In conclusion (1895-2000)}

In this paper we have presented a brief history. And the shorter and more concise the history, the more subjective it will be. However, this overview provides some data and some conclusions such as:

Motorbikes are relatively infrequent in film. If we accept the total number of feature films and documentaries in imdb.com until 2000 (about 280,000 titles), the percent of films with a significant presence of motorcyclists is less than one. And it is not the $1 \%$ outlaw. We must admit that we have not looked for Asiatic films, which include Bollywood. But, although we cannot know for certain, we can venture to suggest that the portrayal of the bike would not change too much.

The only genre directly associated with motorcycles is the biker film, with gangs, violence and leather. Notwithstanding, there are more bike movies with police than with criminals. Individual scenes draw the picture of the bike more than biker movies, but the stereotypes of masculinity, youth, music, freedom, danger, chases, races, riding in groups or 
alone were maintained during the century, with big bikes and even scooters. Other stereotypes are very modern, for instance, the association of the bike with mid-life crisis or of purchasing power and a high standard of living.

However you look at it, bikes are attractive in film. And they are also a narrative and semiotic exception. Despite its scarce presence, the motorbike is so powerful visually as to define a character very accurately: there are bikes for good and bad guys, for men and women, for ordinary and extraordinary people, even for ninjas or zombies.

\section{REFERENCES}

Alford, Steven E., and Suzanne Ferriss. Motorcycle. London: Reaktion Books, 2007.

Atlas Ilustrado de la Vespa. Una aventura sobre ruedas. Barcelona: Susaeta, 2009.

Caneppele, Paolo. Film di viaggio. Turismo in Europa negli anni '20. Gruppo Editoriale Giunti, 2010.

Gras, Marc. Biker Films. Barcelona: Quarentena Ediciones, 2010.

Lagergren, Lars. "Make Way for the Biker: Media and Swedish Motorcycle Culture". International Journal of Motorcycle Studies, 2007.

Mugno, Christina Marie. "The cinema of Mabel Normand". ETD Collection for Wayne State University., 1998.

Osgerby, Bill. Biker: Truth and Myth: How the Original Cowboy of the Road Became the Easy Rider of the Silver Screen. Lyons Press, 2005.

Perlman, Allison. "The Brief Ride of the Biker Movie". International Journal of Motorcycle Studies, 2007.

Sayre, Shay, and Cynthia King. Entertainment and Society: Influences, Impacts, and Innovations. New York and London: Routledge, 2010.

Seate, Mike. Two wheels on two reels A history of biker movies. New Hampshire: Whitehorse Press, 2000.

Thompson, Hunter S. Hell's Angels: A Strange and Terrible Saga of the Outlaw Motorcycle Gangs. New York: Random House, 1967. 
Thompson, William E. Hogs, Blogs, Leathers and Lattes. The Sociology of Modern American Motorcycling. North Carolina: McFarland and Company Inc., 2012.

Wooley, John, and Michael H. Price. The Big Book of Biker Flicks. 40 of the best motorcycle movies of all time. China: Hawk, 2005.

\section{Online Databases:}

www.imdb.com

www.imcdb.org 


\section{ENDNOTES}

${ }^{1}$ There is no more data about this movie which is in the British Film Institute archive.

${ }^{2}$ At http://ftvdb.bfi.org.uk/sift/title/41261?view=synopsis

${ }^{3}$ Meet the Keystone Kops (1955) is a tribute preformed by Abbott \& Costello and includes a funny scene of a motorbike with sidecar.

${ }^{4}$ The Hazards of Helen was an adventure series rival of The Perils of Pauline that became an enormous box-office success. The story of these second series and its main actress, Pearl White, was told in The Perils of Pauline (1947) and includes a bike scene.

${ }^{5}$ Helen Gibson was regarded as the first American cinema stuntwoman. She was a consummate bike and horse rider.

${ }^{6}$ War and the Motorcycle (USA, 1918) was a short documentary above released as a splits with the documentary "Hawaii and her Natives" and a cartoon (imdb.com)

${ }^{7}$ Paolo Caneppele has written a book about the film: “Der Kilometerfresser. I film di viaggio dell'Europa degli anni '20".

${ }^{8} \mathrm{http}: / /$ www.charley-chase.com

${ }^{9}$ Edgar Dearing performed in 342 films, according to imdb.com

${ }^{10}$ More information at Svenska Filminstitutet

${ }^{11}$ Heimatfilm is the name given to a film genre that was popular in Germany, Switzerland and Austria from the late 1940s to the early 1970 s.

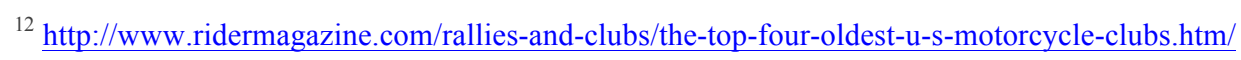

${ }^{13}$ He played the role of "Mouse" in the movie.

${ }^{15}$ http://www.warholstars.org/chron/BatmanDrac64n9.html

${ }^{16}$ Regardless of films that continue the biker genre of previous decades.

${ }^{17}$ The same year, there is another case of a brand name in the title: Harley (1991) 